\title{
KESULITAN BELAJAR MATEMATIKA SISWA KELAS X DITINJAU DARI TAKSONOMI BLOOM REVISI RANAH KOGNITIF
}

\author{
Maghfira Maulani ${ }^{1}$, Mochammad Alipatan ${ }^{2}$, Husnul Khotimah ${ }^{3}$ \\ Universitas Balikpapan ${ }^{1}$, Universitas Balikpapan ${ }^{2}$, Universitas Balikpapan ${ }^{3}$ \\ pos-el: maghfira.maulani@gmail.com ${ }^{1}$, alipatan9@yahoo.co.id ${ }^{2}$, husnul.khotimah@uniba-bpn.ac.id ${ }^{3}$
}

\begin{abstract}
ABSTRAK
Penelitian ini membahas tentang tingkat kesulitan belajar matematika siswa ditinjau dari taksonomi bloom revisi ranah kognitif siswa kelas X. Penelitian ini bertujuan untuk mendeskripsikan jenis kesulitan serta faktor yang menyebabkan kesulitan belajar Matematika yang dialami siswa kelas X di SMAIT Al Auliya Balikpapan. Jenis penelitian ini adalah penelitian deskriptif kualitatif yang dianalisis dengan menggunakan pendekatan deskriptif. Subjek dalam penelitian ini sebanyak 58 siswa. Subjek yang terpilih dalam wawancara sebanyak 12 siswa yang ditentukan dari tes diagnostiknya. Siswa yang terpilih sebagai subjek wawancara diambil dari hasil tes terendah pada setiap tingkatan kognitif. Data dikumpulkan dengan metode tes, wawancara, observasi, dan dokumentasi. Hasil penelitian menunjukkan bahwa rata-rata persentase kesulitan belajar matematika siswa kelas X SMAIT Al Auliya Balikpapan berdasarkan ranah kognitif taksonomi bloom revisi, yaitu kesulitan pada tahap mengingat $41 \%$; kesulitan pada tahap memahami $63,5 \%$; kesulitan pada tahap menerapkan $68,75 \%$; kesulitan pada tahap menganalisis $77,25 \%$. Selain itu, faktor internal yang menyebabkan kesulitan belajar matematika siswa yaitu kurangnya minat belajar siswa, kurangnya pemahaman baik materi maupun soal yang diberikan, kurangnya daya ingat siswa pada rumus-rumus persamaan kuadrat, kurangnya keahlian dalam menghitung, dan faktor eksternal yang menyebabkan kesulitan belajar matematika siswa yaitu kurangnya perhatian dan dukungan dari keluarga.
\end{abstract}

Kata kunci : kesulitan matematika, taksonomi bloom

\section{ABSTRACT}

This research discusses the level of learning difficulties of mathematics students reviewed from the taxonomy bloom revision of the cognitive realm of grade $X$ students. This research aims to describe the types of difficulties and factors that cause learning difficulties in Mathematics experienced by grade X students at SMAIT Al Auliya Balikpapan. This type of research is qualitative descriptive research analyzed using descriptive approach. The subjects in the study were 58 students. The subjects selected in the interview were 12 students who were determined from their diagnostic tests. Students selected as interview subjects were taken from the lowest test results at each cognitive level. Data is collected by test methods, interviews, observations, and documentation. The results showed that the average percentage of math learning difficulties of grade X students SMAIT Al Auliya Balikpapan based on the realm of cognitive taxonomy bloom revision, namely difficulty in the considering stage of $41 \%$; difficulty at the stage of understanding $63.5 \%$; difficulty at the stage of applying $68.75 \%$; difficulty at the stage of analyzing $77.25 \%$. Other than that, the internal factors that cause students math learning difficulties are the lack of interest in learning students, lack of understanding of both materials and problems given, lack of student memory in quadratic equation formulas, lack of expertise in counting, and external factors that cause students learning difficulties, namely lack of care and support from the family. Keywords: mathematics difficulties, taxonomy bloom

\section{PENDAHULUAN}

Matematika merupakan salah satu mata pelajaran yang perannya tidak terlepas dari berbagai aspek kehidupan.
Selain itu, dengan mempelajari matematika seseorang terbiasa berpikir secara sistematis, ilmiah, menggunakan logika, kritis, serta dapat meningkatkan 
daya kreativitasnya. Cockroft (Suryawati \& Zulfikar, 2012) mengemukakan bahwa matematika perlu diajarkan kepada siswa karena selalu digunakan dalam segala segi kehidupan, semua bidang studi memerlukan keterampilan matematika yang sesuai, merupakan sarana komunikasi yang kuat, singkat, dan jelas, dapat digunakan untuk menyajikan informasi dalam berbagai cara, meningkatkan kemampuan berpikir logis, ketelitian, dan kesadaran ke ruangan, memberikan kepuasan terhadap usaha memecahkan masalah yang menantang. Mengingat pentingnya matematika dalam kehidupan sehari - hari, maka matematika perlu dipahami dan dikuasai oleh semua lapisan masyarakat tak terkecuali siswa sekolah sebagai generasi penerus.

Keberhasilan dalam kegiatan belajar mengajar matematika dapat diukur dari tingkat pemahaman, penguasaan materi, serta prestasi belajar siswa. Namun, pada kenyataannya masih banyak siswa khususnya siswa SMA yang mengalami kesulitan pada pembelajaran matematika. Berdasarkan wawancara dengan beberapa siswa di SMAIT Al Auliya Balikpapan, beberapa siswa merasa kesulitan pada pembelajaran matematika. Guru matematika SMAIT Al Auliya pun menuturkan bahwa $35 \%$ siswa mendapatkan nilai di bawah KKM, serta kesulitan yang sering dialami oleh siswa yaitu kesulitan saat mengerjakan soal uraian atau essai dan soal cerita. Kemudian pada saat pembelajaran berlangsung, siswa terlihat kurang aktif saat diberi permasalahan matematika dan hanya ada beberapa siswa yang berani maju di depan kelas. Beberapa siswa juga terlihat tidak fokus mengikuti pembelajaran, seperti membaca buku yang tidak ada kaitannya dengan pelajaran matematika, dan ada pula yang mengobrol dengan teman di sebelahnya.

Pada observasi saat proses pembelajaran berlangsung, guru kurang memanfaatkan media pendukung yang dapat memperjelas materi dan memudahkan siswa dalam memahami materi yang disampaikan. Metode yang monoton, guru kurang menguasai kelas serta kurangnya interaksi pada saat pembelajaran berlangsung turut menyebabkan siswa kesulitan belajar matematika. Akibat lebih jauh dari kesulitan belajar yang dialami siswa adalah terhambatnya proses belajar siswa itu sendiri sehingga hasil belajar siswa rendah. Hal tersebut dibuktikan dengan banyaknya siswa yang belum memenuhi kriteria ketuntasan minimal (KKM) yaitu 70.

Sebagai upaya untuk mengetahui tingkat keberhasilan peserta didik dalam mencapai tujuan pembelajaran yang ditetapkan, maka evaluasi hasil belajar memiliki sasaran tertentu yang terkandung dalam tujuan pembelajaran tersebut. Pada kurikulum 2013, pengelompokan tujuan pembelajaran harus mengacu kepada tiga jenis domain yang melekat pada diri peserta didik yang disebutkan oleh Benjamin S. Bloom yang dikenal dalam Taksonomi Bloom, yaitu ranah proses berpikir (cognitive domain), ranah nilai atau sikap (affective domain), dan ranah keterampilan (psychomotor domain) (Khasanah, 2015, p.6). Ketiga ranah tersebut merupakan aspek dalam penilaian yang dijadikan titik perhatian yang akan diketahui statusnya berdasarkan pengukuran.

Pada penelitian ini, aspek yang dipilih oleh peneliti yaitu aspek atau ranah kognitif. Hal ini karena ranah kognitif berperan utama dalam ketuntasan hasil belajar siswa dan digunakan untuk menentukan tercapai atau tidaknya tujuan pembelajaran karena berkaitan dengan kemampuan siswa dalam menguasai pelajaran. Bloom dan kawan - kawan dalam Amelia, dkk (2015, p.2) mengemukakan bahwa dari evaluasi hasil belajar yang banyak disusun sekolah, ternyata persentase terbanyak butir soal yang diajukan hanya meminta siswa untuk mengutarakan hafalan mereka. Menurut Bloom, hafalan sebenarnya merupakan 
tingkatan terendah dalam kemampuan berpikir (thinking behavior). Masih banyak level lain yang lebih tinggi yang harus dicapai agar proses pembelajaran dapat menghasilkan siswa yang kompeten dibidangnya. Ranah kognitif terdiri atas enam level, yaitu : (1) pengetahuan (knowlegde),

(comprehension),

(3) aplikasi (application), (4) analisis (analysis), (5) sintesis (synthesis), dan (6) evaluasi (evaluation).

Anderson \& Krathwohl (2010, p.99) mendefinisikan kategori mengingat adalah mengambil pengetahuan yang relevan dari memori jangka panjang seorang siswa. Mengingat meliputi mengenali (recognition) dan memanggil kembali (recalling). Mengenali berkaitan dengan mengetahui pengetahuan masa lampau yang berkaitan dengan hal-hal yang konkret, sedangkan memanggil kembali adalah proses kognitif yang membutuhkan pengetahuan masa lampau secara cepat dan tepat. Mengingat berhubungan erat dengan daya ingat seseorang.

Mania (2012) menjelaskan makna memahami adalah tingkat kemampuan yang mengharapkan peserta didik untuk mampu memahami arti atau konsep, situasi, serta fakta yang diketahuinya. Dalam hal ini peserta didik tidak hanya hafal secara verbalis, tetapi memahami konsep dari masalah atau fakta yang ditanyakan. Anderson \& Krathwohl (2010, p.106-115) menyatakan bahwa dalam kategori memahami ada tujuh proses kognitif yaitu menafsirkan, mencontohkan, mengklasifikasikan, merangkum, menyimpulkan, membandingkan dan menjelaskan.

Kategori menerapkan didefinisikan oleh Anderson \& Krathwohl (2010, p.116) sebagai kategori dari proses kognitif yang meliputi penggunaan prosedur atau cara kerja tertentu untuk mengerjakan suatu latihan atau menyelesaikan suatu masalah. Menerapkan berkaitan dengan dimensi pengetahuan prosedural (procedural knowledge). Dalam kategori ini terdapat dua proses kognitif yaitu mengeksekusi / menjalankan prosedur (executing) dan mengimplementasi (implementing).

Kategori menganalisa didefinisikan oleh Anderson \& Krathwohl (2010, p.120) sebagai bentuk usaha mengurai materi menjadi bagian - bagian penyusunnya dan menentukan hubungan antara bagianbagian penyusunnya tersebut dengan materi tersebut secara keseluruhan. Hal tersebut menekankan pada kemampuan merinci sesuatu unsur pokok menjadi suatu bagian-bagian dan dapat melihat hubungan antar bagian tersebut. Pada tingkat analisis, seseorang akan mampu menganalisa informasi yang masuk, membagi dalam bentuk yang lebih kecil untuk memahami pola atau hubungan serta dapat mengenali dan membedakan faktorfaktor penyebab dan akibatnya. Kategori menganalisa terdiri dari kemampuan membedakan, mengorganisasi, dan memberi simbol.

Kategori mengevaluasi diartikan oleh Anderson \& Krathwohl (2010, p.125) sebagai membuat keputusan berdasarkan kriteria dan standar. Kategori dalam evaluasi mencakup checking dan critiquing.

Menurut Anderson \& Krathwohl (2010, p.128), mencipta merupakan menempatkan bagian-bagian secara bersama-sama ke dalam suatu ide, semuanya saling berhubungan untuk membuat hasil yang baik. Selain itu, mencipta didefinisikan menggeneralisasikan ide baru atau cara pandang yang baru, dan produk baru. Siswa dapat dikatakan create bila dapat membuat produk baru dengan merombak beberapa bagian ke dalam bentuk atau struktur yang belum pernah diterangkan oleh guru sebelumnya. Pada umumnya, proses create berhubungan dengan pengalaman belajar siswa sebelumnya. Proses create dapat dipecah menjadi tiga fase yaitu merumuskan, merencanakan, dan memproduksi.

Sesuai dengan hasil wawancara kepada guru mata pelajaran matematika di 
SMAIT Al- Auliya Balikpapan menyatakan bahwa evaluasi hasil belajar yang diterapkan di SMAIT Al Auliya mengacu pada Taksonomi Bloom olahan Krathwohl yang terbagi menjadi tiga aspek, yaitu ranah sikap, ranah pengetahuan/kognitif, dan ranah keterampilan. Akan tetapi, evaluasi hasil belajar siswa pada ranah pengetahuan/kognitif yang diterapkan baru sampai tingkat berpikir menganalisis. Hal ini dikarenakan kemampuan berpikir setiap siswa memiliki tingkatan yang berbeda, sehingga guru matematika bersama dengan waka kurikulum mencoba mencari solusi terbaik agar pelajaran matematika tidak menjadi beban bagi siswa yang tingkat berpikirnya rendah.

Permasalahan pembelajaran matematika tersebut didukung penelitian yang dilakukan oleh Novferma (2016), menyatakan bahwa jenis kesulitan yang dialami siswa yaitu pada mengingat fakta, mengingat konsep, memahami fakta, memahami konsep, mengevaluasi prosedur, dan mengomunikasikan metakognitif. Faktor - faktor kesulitan yang dialami siswa dalam memecahkan masalah matematika berbentuk soal cerita yaitu siswa merasa waktu yang diberikan tidak cukup, mudah menyerah, kurang teliti, sering lupa, merasa cemas, dan siswa tergesa-gesa untuk mengerjakan soal.

Selanjutnya penelitian dari Tias \& Dhoriva (2015), menyatakan bahwa kesulitan matematika siswa terletak pada kesulitan mengingat fakta, kesulitan memahami fakta, kesulitan menerapkan fakta, kesulitan menganalisis fakta, kesulitan mengingat konsep, kesulitan memahami konsep, kesulitan menerapkan konsep, kesulitan menganalisis konsep, kesulitan memahami prosedur, kesulitan menerapkan prosedur, kesulitan menganalisis prosedur, kesulitan mengingat konsep visual-spasial, kesulitan menerapkan visual-spasial, kesulitan menganalisis visual-spasial. Faktor-faktor kesulitan yang dialami siswa SMA dalam memecahkan masalah matematika yakni: siswa kurang teliti, tergesa-gesa dalam mengerjakan soal, lupa, kurang waktu untuk mengerjakan soal, cepat menyerah, terkecoh, dan cemas.

Penelitian ini berbeda dengan penelitian yang relevan tersebut. Fokus penelitian ini adalah deskripsi persentase tiap jenis kesulitan matematika siswa kelas X SMAIT Al Auliya Balikpapan ditinjau dari taksonomi bloom revisi. Abdurrahman (2010: 11) mengemukakan bahwa secara garis besar kesulitan belajar dapat diklasifikasikan ke dalam dua kelompok: (1) kesulitan belajar yang berhubungan dengan perkembangan peserta didik; dan (2) kesulitan belajar akademik. Dalam penelitian ini kesulitan belajar yang akan dibahas peneliti yaitu kesulitan belajar akademik.

Berdasarkan latar belakang tersebut, penelitian ini penting untuk mengetahui jenis kesulitan matematika siswa serta faktor yang menyebabkan siswa kesulitan belajar matematika khususnya di kelas $\mathrm{X}$, karena kelas X merupakan awal di jenjang SMA yang berperan sebagai pondasi keilmuan siswa. Informasi yang diperoleh dari penelitian ini diharapkan dapat mengurangi kesulitan belajar matematika di kelas $X$, sehingga kesulitan tersebut tidak berlanjut di kelas XI dan kelas XII.

\section{METODE PENELITIAN}

Pendekatan penelitian ini merupakan kualitatif dengan studi kasus. Penelitian dilakukan di SMAIT Al Auliya Balikpapan pada semester ganjil tahun ajaran 2019/2020. Data dalam penelitian ini adalah hasil tes siswa berdasarkan taksonomi bloom ranah kognitif, serta hasil wawancara kepada siswa dan guru untuk mengetahui faktor internal kesulitan belajar siswa.

Tes dilakukan kepada seluruh siswa kelas $\mathrm{X}$ yang berjumlah empat kelas atau 58 siswa. Soal tes yang diberikan berupa soal isian berjumlah 16 butir soal yang memuat keempat unsur tingkatan taksonomi bloom revisi, yaitu tingkatan mengingat, memahami, menerapkan, dan 
menganalisis. Soal tes yang digunakan pada penelitian ini diambil dari buku matematika kelas X kurikulum 2013 edisi revisi tahun 2016 terbitan Erlangga, kemudian soal yang telah peneliti kumpulkan dan peneliti pilah sesuai dengan tingkatan kognitif diperiksa dan divalidasi oleh guru Matematika.

Hasil dari tes tersebut berupa nilai yang peneliti urutkan berdasarkan empat tingkatan taksonomi bloom revisi yaitu mengingat (C1), memahami (C2), menerapkan (C3), dan menganalisa (C4). Kemudian peneliti mengambil 3 orang siswa dengan hasil tes yang rendah pada masing-masing tingkatan taksonomi bloom revisi untuk diwawancara mendalam, sehingga didapatkan 12 orang siswa yang mengalami kesulitan belajar matematika berdasarkan hasil tes taksonomi bloom revisi. Siswa tersebut dipilih secara purposive yang memperhatikan kemampuan kominukasi.

Keabsahan data penelitian ini menggunakan triangulasi sumber dan triangulasi teknik atau metode pengumpulan data yang berupa wawancara dengan narasumber secara langsung dan dokumen yang berisi catatan terkait dengan data yang diperlukan oleh peneliti.

\section{HASIL DAN PEMBAHASAN}

Hasil penelitian ini, siswa yang mengalami kesulitan belajar matematika terindikasi dengan persentase rata-rata respons siswa dalam menjawab soal tes dengan salah, yaitu sebesar $61,75 \%$. Sedangkan siswa yang menjawab soal tes dengan benar hanya sebesar 38,25\%. Dari data tersebut dapat dilihat bahwa kesulitan matematika siswa tinggi. Kondisi tersebut seperti yang dikemukakan oleh Supartini (Suwarto, 2013, p.85-86) mendefinisikan kesulitan belajar sebagai kegagalan dalam mencapai tujuan belajar, ditandai dengan tidak menguasai minimal, tidak dapat mencapai prestasi yang semestinya, tidak dapat mewujudkan tugas-tugas perkembangan, tidak dapat mencapai tingkat penguasaan yang diperlukan sebagai prasyarat bagi kelanjutan untuk belajar di tingkat selanjutnya.

Kemudian masih banyak siswa yang menganggap matematika merupakan pelajaran yang sulit. Siswa menganggap matematika tentang persamaan kuadrat, pertidaksamaan irasional, dan sistem persamaan linear dalam kehidupan seharihari merupakan materi yang sulit. Alasannya karena siswa merasa bingung ketika menyelesaikan soal - soal yang berkaitan dengan materi tersebut. Abu Ahmadi dan Widodo S. (2004, p.77) mengungkapkan bahwa, kesulitan belajar berarti siswa tidak dapat belajar sebagaimana mestinya.

Guru matematika juga mengungkapkan bahwa beberapa siswa bersikap negatif saat pembelajaran matematika. Seperti tidak mengikuti pembelajaran matematika dengan baik, siswa tidak memperhatikan penjelasan yang disampaikan guru dan melakukan aktivitas lain saat pelajaran seperti mengobrol dengan temannya. Sebagaimana dikemukakan Kusdaryani dan Trimo (2009, p.146) bahwa kesulitan belajar mencakup: Learning disabilities (tidak mampu belajar) adalah siswa yang tidak mampu atau menghindari belajar sehingga hasil belajarnya lebih rendah dari potensi intelektualnya, Learning disfunction (belajar tidak berfungsi) adalah proses belajar yang tidak berfungsi dengan baik, meskipun siswa tidak menunjukkan adanya ketidaknormalan mental, gangguan alat indra, atau gangguan psikologis lainnya.

Mengingat merupakan aspek yang paling rendah dalam taksonomi bloom yang telah direvisi. Anderson \& Krathwohl (2010, p.99) mendefinisikan kategori mengingat adalah mengambil pengetahuan yang relevan dari memori jangka panjang seorang siswa. Mengingat meliputi mengenali (recognition) dan memanggil kembali (recalling). Mengenali berkaitan dengan mengetahui pengetahuan masa lampau yang berkaitan 
dengan hal-hal yang konkret, sedangkan memanggil kembali adalah proses kognitif yang membutuhkan pengetahuan masa lampau secara cepat dan tepat.

Dalam penelitian ini, rata - rata siswa yang mengalami kesulitan dalam tingkat berpikir $\mathrm{C} 1$ (mengingat) sebesar $41 \%$. kesulitan yang paling dominan yang dialami siswa pada aspek mengingat yaitu siswa tidak dapat mengidentifikasi bentuk umum dari pertidaksamaan irasional, yaitu sebesar $64 \%$.

Tabel 1. Persentase Siswa yang Kesulitan dalam Level Kognitif Mengingat (C1)

\begin{tabular}{|c|c|c|c|}
\hline $\begin{array}{l}\text { NO. } \\
\text { SOAL }\end{array}$ & INDIKATOR & \multicolumn{2}{|c|}{$\begin{array}{l}\text { PERSENTASE } \\
(\%)\end{array}$} \\
\hline 1 & Menyebutkan persamaan garis dalam bentuk persamaan umum & $17 \%$ & \multirow{4}{*}{$41 \%$} \\
\hline 2 & Mengidentifikasi bentuk umum dari pertidaksamaan irasional & $64 \%$ & \\
\hline 3 & $\begin{array}{l}\text { Menyebutkan bentuk umum dari sistem persamaan linear dua } \\
\text { variabel }\end{array}$ & $47 \%$ & \\
\hline 4 & Menyebutkan bentuk umum dari persamaan lingkaran & $36 \%$ & \\
\hline
\end{tabular}

Berdasarkan hasil wawancara, siswa mengaku tidak dapat mengidentifikasi bentuk umum dari pertidaksamaan irasional karena kurang menguasai materi tersebut sehingga menjawab pertanyaan tersebut dengan cara menebak - nebak. Hal ini berarti siswa kesulitan dalam mengingat kembali materi yang telah di pelajari sebelumnya.

Anderson \& Krathwohl (2010, p.99) mendefinisikan kategori mengingat adalah mengambil pengetahuan yang relevan dari memori jangka panjang seorang siswa. Kemampuan seseorang dalam mengetahui atau mengingat pengetahuan tidak terlepas dari kemampuan daya ingat. Sebagaimana yang dipaparkan oleh Chaplin (2005), bahwa daya ingat merupakan kemampuan seseorang untuk memanggil kembali informasi yang telah dipelajarinya dan yang telah disimpan dalam otak. Hal ini sejalan dengan pendapat Oemarjoedi (2003) bahwa pengetahuan adalah faktor penentu bagaimana manusia berpikir, merasa dan bertindak.

Hasil penelitian ini, rata - rata siswa yang mengalami kesulitan dalam tingkat berfikir C2 (memahami) sebesar $63,5 \%$. Dan kesulitan yang paling dominan yang dialami siswa pada aspek memahami yaitu dalam menginterpretasikan syarat-syarat yang berhubungan dengan pertidaksamaan kuadrat, yaitu sebesar $76 \%$.

Tabel 2. Persentase Siswa yang Kesulitan dalam Level Kognitif Memahami (C2)

\begin{tabular}{|c|c|c|c|}
\hline $\begin{array}{l}\text { NO. } \\
\text { SOAL }\end{array}$ & INDIKATOR & \multicolumn{2}{|c|}{$\begin{array}{l}\text { PERSENTASE } \\
(\%) \\
\end{array}$} \\
\hline 5 & Memberi contoh nilai mutlak dari suatu bilangan real & $66 \%$ & \multirow{4}{*}{$63,5 \%$} \\
\hline 6 & Merubah suatu kalimat deskriptif menjadi kalimat matematika & $57 \%$ & \\
\hline 7 & $\begin{array}{l}\text { Mengkategorikan sistem persamaan linear yang mempunyai } \\
\text { penyelesaian tunggal }\end{array}$ & $55 \%$ & \\
\hline 8 & $\begin{array}{l}\text { Menginterpretasikan syarat-syarat yang berhubungan dengan } \\
\text { pertidaksamaan kuadrat }\end{array}$ & $76 \%$ & \\
\hline
\end{tabular}

Berdasarkan hasil wawancara, siswa tidak bisa menjawab pertanyaan peneliti dengan benar yang berkaitan dengan soal matematika tingkat kognitif C2 (memahami) pada materi pertidaksamaan kuadrat, nilai mutlak, dan persamaan linear. Siswa mengungkapkan bahwa ia 
mengerjakan soal tersebut dengan menegasikannya. Hal ini berarti siswa masih belum memahami perbedaan dari pernyataan yang setara dan negasi dari sebuah pernyataan.

Selanjutnya, peneliti memberikan pertanyaan kepada siswa berupa soal yang berkaitan dengan menyederhanakan bentuk aljabar yang memuat bentuk logaritma. Dari hasil wawancara dengan siswa, siswa mengungkapkan bahwa ia menggunakan beberapa sifat-sifat logaritma dalam menjawab soal tersebut. Hal ini berarti siswa dapat mengingat beberapa sifat-sifat logaritma dengan baik.

Namun, siswa tidak menyelesaikannya hingga akhir hingga menjadi persamaan seperti yang diperintahkan oleh soal. Hal ini berarti siswa tidak dapat mengubah

Tabel 3. Persentase Siswa yang Kesulitan dalam Level Kognitif Menerapkan (C3)

\begin{tabular}{|c|l|c|c|}
\hline $\begin{array}{c}\text { NO. } \\
\text { SOAL }\end{array}$ & \multicolumn{1}{|c|}{ INDIKATOR } & $\begin{array}{c}\text { PERSENTASE } \\
(\%)\end{array}$ \\
\hline 9 & Mengeksekusi nilai mutlak secara prosedural & $66 \%$ & \\
\hline 10 & $\begin{array}{l}\text { Menentukan himpunan penyelesaian dari sistem pertidakasamaan } \\
\text { kuadrat satu variabel }\end{array}$ & $71 \%$ & \multirow{2}{*}{$68,75 \%$} \\
\cline { 1 - 3 } 11 & Menentukan himpunan penyelesaian dari sistem persamaan linear & $66 \%$ & $72 \%$ \\
\cline { 1 - 2 } 12 & Menentukan persamaan garis yang saling tegak lurus & \\
\hline
\end{tabular}

Berdasarkan hasil wawancara, siswa kesulitan dalam menjawab pertanyaan peneliti dengan benar yang berkaitan dengan soal matematika tingkat kognitif C3 (menerapkan) pada materi sistem pertidaksamaan dua variabel (linearkuadrat dan kuadrat-kuadrat). Siswa menuturkan bahwa awalnya ia merasa bingung untuk menyelesaikan soal tersebut dan membutuhkan waktu yang tidak singkat dalam menyelesaikan soal tersebut. Lerner (2006, p.479) mengemukakan bahwa, kesulitan matematika memiliki karakteristik tertentu, yakni kesulitan dalam memproses informasi, kesulitan yang berkaitan dengan kemampuan bahasa dan membaca serta kecemasan matematika.

Walaupun begitu, rumus yang siswa gunakan sudah tepat. Hanya saja dalam informasi dari satu bentuk penyajian ke bentuk penyajian lainnya. Sebagaimana yang dipaparkan Anderson \& Krathwohl (2010, p.106-115) yaitu, menghubungkan kategori memahami dengan proses menginterpretasikan (interpreting). Proses menginterpretasikan terjadi pada siswa jika siswa mampu mengubah informasi dari satu bentuk penyajian ke bentuk penyajian lainnya.

Hasil penelitian pada kategori menerapkan yaitu rata-rata siswa yang mengalami kesulitan sebesar 68,75\%. Kesulitan paling dominan yang dialami siswa pada aspek menerapkan yaitu siswa tidak dapat menentukan persamaan garis yang saling tegak lurus yaitu sebesar $72 \%$. proses menghitung siswa mengalami kesulitan. Kesulitan tersebut yaitu ketika siswa merasionalkan penyebut pecahan bentuk akar dan ketika memasukkan data ke dalam persamaan. Hal ini berarti siswa kesulitan dalam menjalankan prosedur. Kondisi ini sesuai dengan pendapat Larkin (2010, p.10) yang menyatakan bahwa pengetahuan prosedural adalah pengetahuan tentang cara bagaimana melakukan sesuatu. Teori ini diperkuat dengan pendapat Anderson \& Krathwohl (2010, p.116) bahwa, kategori menerapkan berkaitan dengan dimensi pengetahuan prosedural (procedural knowledge). Menjalankan prosedur merupakan proses kognitif siswa dalam menyelesaikan masalah dan melaksanakan percobaan dimana siswa sudah mengetahui informasi 
tersebut dan mampu menetapkan prosedur apa saja yang harus dilakukan.

Hasil penelitian pada kategori menganalisis yaitu rata - rata siswa yang mengalami kesulitan sebesar 58\%. Kesulitan yang paling dominan yang dialami siswa pada aspek menganalisa yaitu siswa tidak dapat memecahkan masalah yang berhubungan dengan sistem persamaan kuadrat dalam kehidupan sehari-hari, yaitu sebesar 79\%.

Tabel 4. Persentase Siswa yang Kesulitan dalam Level Kognitif Menganalisis (C4)

\begin{tabular}{|c|l|c|}
\hline $\begin{array}{c}\text { NO. } \\
\text { SOAL }\end{array}$ & \multicolumn{1}{|c|}{ INDIKATOR } & \multicolumn{1}{|c|}{$\begin{array}{c}\text { PERSENTASE } \\
(\%)\end{array}$} \\
\hline 13 & $\begin{array}{l}\text { Menganalisis permasalahan yang berhubungan dengan } \\
\text { pertidaksamaan linear }\end{array}$ & $71 \%$ \\
\hline 14 & $\begin{array}{l}\text { Memecahkan masalah yang berhubungan dengan } \\
\text { pertidaksamaan rasional dalam kehidupan sehari-hari }\end{array}$ & $83 \%$ \\
\hline 15 & $\begin{array}{l}\text { Memecahkan masalah yang berhubungan dengan sistem } \\
\text { persamaan linear dalam kehidupan sehari-hari }\end{array}$ & $76 \%$ \\
\hline 16 & $\begin{array}{l}\text { Memecahkan masalah yang berhubungan dengan sistem } \\
\text { persamaan kuadrat dalam kehidupan sehari-hari }\end{array}$ & $79 \%$ \\
\hline
\end{tabular}

Berdasarkan hasil wawancara, siswa kesulitan dalam menjawab pertanyaan peneliti dengan benar yang berkaitan dengan soal matematika tingkat kognitif C4 (menganalisa) pada materi sistem persamaan dan pertidaksamaan kuadrat. Siswa mengungkapkan bahwa ia kesulitan ketika menentukan persamaan untuk mencari ukuran panjang dan lebar persegi tersebut. Karna yang diketahui pada soal yaitu keliling dan luasnya. Siswa juga mengungkapkan bahwa ia harus membaca soal dengan berulang - ulang. Kemudian siswa juga melakukan kesalahan dalam mengoperasikan aljabar. Hal ini dapat diartikan bahwa siswa kesulitan dalam mengorganisasikan. Anderson \& Krathwohl (2010, p.120) memaparkan bahwa menganalisis berkaitan dengan proses kognitif memberi atribut (attributeing) dan mengorganisasikan (organizing). Mengorganisasikan memungkinkan siswa membangun hubungan yang sistematis dan koheren dari potongan-potongan informasi yang diberikan.

Hasil analisis faktor penyebab kesulitan secara internal sesuai dengan yang ungkapkan oleh Slameto (2010:188) bahwa faktor yang mempengaruhi hasil belajar adalah sikap. Sikap positif terhadap suatu mata pelajaran adalah awal yang baik untuk proses pembelajaran. Sebaliknya sikap negatif terhadap mata pelajaran akan berpotensi menimbulkan kesulitan belajar atau membuat hasil belajar yang kurang maksimal.

Dari pernyataan siswa dalam hasil wawancara, siswa tidak menyukai pelajaran matematika dan mempunyai sikap negatif terhadap pembelajaran matematika. Sehingga siswa tidak mengikuti pembelajaran dengan baik. Sikap tersebut ditunjukkan dengan bertindak gaduh dan tidak memperhatikan ketika pembelajaran matematika berlangsung. Selain itu, sikap negatif juga ditunjukkan dengan siswa yang tidak antusias, siswa cenderung tidak aktif dalam pembelajaran.

Motivasi berfungsi mengarahkan perbuatan siswa dalam belajar. Hasil analisis menunjukkan bahwa motivasi belajar siswa masih rendah siswa tidak memperhatikan penjelasan guru dengan baik, padahal di awal pembelajaran guru sudah memberikan motivasi kepada siswa agar dapat mengikuti pembelajaran dengan serius dan penuh konsentrasi.

Selain itu, motivasi siswa dapat diketahui dari persiapan siswa dalam belajar matematika. Siswa dengan 
motivasi yang kuat akan senang belajar matematika meskipun tidak ada PR atau ulangan keesokan harinya. Namun siswa yang terindikasi kesulitan belajar matematika memiliki motivasi yang rendah, mereka tidak mengulang kembali materi yang telah disampaikan atau mempelajari terlebih dahulu materi yang akan disampaikan. Rendahnya motivasi siswa juga mengakibatkan siswa tidak antusias mengikuti pembelajaran matematika sehingga menimbulkan kesulitan belajar matematika. Hal ini sesuai dengan pendapat Ahmadi dan Supriyono (2013) bahwa siswa yang motivasinya lemah tampak acuh tak acuh, mudah putus asa dan perhatiannya tidak tertuju pada pelajaran akibatnya banyak mengalami kesulitan belajar.

Motivasi siswa yang rendah diduga karena motivasi dari dalam diri siswa tidak ditanamkan dengan baik oleh orang tua di rumah. Orang tua yang tidak memberikan perhatian secara maksimal akan berdampak pada rendahnya motivasi belajar siswa di sekolah. Motivasi dari dalam diri siswa sendiri atau motivasi instrinsik mempengaruhi hasil belajar siswa. Pernyataan tersebut didukung hasil penelitian Anis Susanti \& Nuriyatin (2015) bahwa motivasi instrinsik siswa mempunyai pengaruh lebih besar terhadap prestasi belajar matematika dari motivasi ekstrinsik.

Pemberian motivasi telah dilakukan oleh guru secara lisan dengan memberikan contoh-contoh sikap yang perlu ditiru agar berhasil dalam belajar. Guru juga memberikan penghargaan untuk memotivasi siswa, namun belum berdampak secara signifikan. Untuk itu, guru dan orang tua perlu memberi perhatian lebih serta bekerja sama untuk selalu meningkatkan motivasi siswa sehingga siswa tidak mengalami kesulitan belajar matematika.

Kesulitan belajar matematika siswa dapat ditimbulkan oleh faktor fisiologis. Hasil analisis menunjukkan bahwa tidak semua siswa mengalami kesulitan belajar matematika yang disebabkan masalah kesehatan. Namun terdapat beberapa siswa yang sering tidak masuk kelas karena sakit sehingga berdampak pada tertinggalnya materi pelajaran matematika.

Masalah kesehatan yang sering muncul dan berdampak pada siswa adalah kondisi fisik siswa yang kurang sehat. Siswa tidak konsentrasi belajar dan mengantuk ketika pelajaran matematika mengindikasikan kondisi fisik tidak dalam keadaan sehat. Keadaan tubuh yang kurang sehat mempengaruhi penerimaan siswa terhadap informasi yang disampaikan. Hal ini sesuai dengan penelitian Silitonga \& Verawati (2019) bahwa tingkat kebugaran jasmani mempengaruhi prestasi belajar siswa.

Dari hasil analisis yang dilakukan ditemukan hanya satu orang siswa yang mengalami gangguan pengindraan, yaitu tidak dapat melihat jauh atau menderita rabun jauh. Gangguan penglihatan yang dialami siswa dapat mengurangi daya serap informasi yang disampaikan oleh guru. Hal ini seperti yang disampaikan oleh Muhibbin Syah (2009) bahwa terganggunya alat pendengaran dan alat penglihatan menjadi faktor internal kesulitan belajar siswa.

Guru sudah mengurangi gangguan kemampuan pengindraan siswa dengan memindahkan tempat duduk siswa di bangku paling depan. Pun dengan siswa juga telah mengurangi gangguan penglihatannya dengan menggunakan kacamata minus. Ada baiknya pihak sekolah bekerja sama dengan ahli kesehatan untuk melakukan pemeriksaan pada kemampuan pengindraan siswa secara berkala. Agar gangguan kemampuan pengindraan pada siswa dapat tertangani dengan baik.

Hasil analisis yang telah dilakukan menunjukkan bahwa guru telah berupaya menggunakan metode yang bervariasi dalam pembelajaran matematika. Guru tidak hanya menggunakan metode ceramah dalam pembelajaran. Guru menggabungkan beberapa metode seperti 
menggabungkan metode ceramah dengan metode kooperatif, penggunaan metode yang dipilih juga disesuaikan dengan materi yang akan diajarkan. Sebagaimana dengan pendapat Subini (2011:34) bahwa cara mengajar guru harus efektif, baik dalam menggunakan model, teknik, ataupun metode dalam mengajar dan disesuaikan dengan konsep yang diajarkan berdasarkan kebutuhan siswa dalam proses belajar mengajar.

Metode yang digunakan guru untuk mengajar pelajaran matematika sudah cukup bervariasi, namun sikap dan cara belajar siswa juga mempengaruhi keberhasilan guru dalam mengajar. Semenarik apa pun model pembelajaran yang digunakan guru, jika siswa mempunyai sikap yang negatif pada pembelajaran matematika siswa tidak akan bersemangat mengikuti pelajaran. Selanjutnya cara belajar siswa yang kurang sesuai dengan model pembelajaran yang digunakan juga membuat siswa kurang antusias mengikuti pelajaran.

Selain model pembelajaran, pentingnya penggunaan media untuk membantu pemahaman siswa sudah disadari oleh guru, maka dari itu guru berupaya untuk menggunakan media dalam pembelajaran matematika. Guru menyadari pentingnya penggunaan media dalam pembelajaran matematika, namun terkadang guru mengalami kendala dalam memilih media yang tepat sesuai dengan materi yang disampaikan. Kurangnya pemahaman akan media yang tepat dan kurangnya kreativitas guru untuk menciptakan media berdampak pada kurangnya pemahaman konsep siswa karena tidak adanya contoh kongkret yang membantu siswa untuk lebih mudah menerima materi. Penggunaan media kongkret dalam pembelajaran sangatlah penting karena siswa berada dalam tahap operasional kongkret dan belum bisa berpikir secara abstrak (Heruman, 2008).

Dari paparan di atas dapat disimpulkan pentingnya penggunaan media dalam pembelajaran matematika. Oleh karena itu, guru hendaknya selalu menambah pengetahuan tentang media pembelajaran inovatif dan interaktif yang dapat digunakan untuk menambah motivasi siswa serta memudahkan siswa dalam menerima materi yang diajarkan.

Sarana dan prasarana di sekolah SMAIT Al Auliya Balikpapan sangat mendukung proses pembelajaran matematika. Pembelajaran matematika selalu berjalan dengan baik. Kemudian kondisi bangunan dapat dikatakan sangat baik karena gedung yang digunakan adalah bangunan yang baru dibangun secara permanen sehingga aman dan nyaman untuk belajar. Ruang kelas yang dilengkapi pendingin udara (AC) memungkinkan pertukaran udara sehingga kelas terasa sejuk dan nyaman untuk belajar. Pada setiap kelas juga terpasang LCD yang dapat membantu guru untuk menyampaikan materi dengan lebih menarik.

Keluarga merupakan pusat pendidikan yang pertama bagi siswa. Bimbingan dari orang tua serta perhatian dari orang tua menjadi faktor penting dalam keberhasilan belajar siswa. dari hasil analisis yang dilakukan diketahui siswa yang terindikasi kesulitan belajar matematika tidak selalu mendapat perhatian dari orang tua di rumah. Kurangnya perhatian dari orang tua disebabkan karena kedua orang tua sibuk bekerja sehingga kurang memperhatikan pelajaran anak di sekoah. Salah satu contoh kurangnya perhatian orang tua yaitu seringnya siswa tidak mengerjakan PR yang diberikan.

Hubungan antar anggota keluarga turut mempengaruhi proses belajar siswa. Kesibukan kedua orang tua dalam bekerja membuat perhatian orang tua terhadap perkembangan pelajaran matematika menjadi kurang maksimal. Hal ini sesuai dengan pendapat Ahmadi dan Supriyono (2013) bahwa anak yang tidak mendapatkan pengawasan atau bimbingan dari orang tua kemungkinan akan banyak mengalami kesulitan belajar. 
Hubungan yang baik antara orang tua dan siswa perlu dibangun agar orang tua senantiasa mengerti kebutuhan dan kesulitan yang dialami oleh siswa. hubungan yang baik dapat dibangun dengan komunikasi dan meluangkan waktu serta mendampingi siswa dalam belajar. Selain itu, orang tua perlu berkomunikasi secara teratur dengan guru tentang perkembangan belajar anaknya di sekolah sehingga kesulitan belajar yang dialami siswa dapat diatasi.

Berdasarkan teori dan hasil penelitian ditemukan proposisi bahwa faktor yang menyebabkan kesulitan belajar matematika terdiri dari faktor internal dan faktor eksternal. Faktor internal meliputi sikap negatif siswa dalam belajar matematika, motivasi belajar siswa yang masih rendah, kesehatan tubuh yang tidak optimal, dan kemampuan pengindraan siswa yang kurang. Sedangkan faktor eksternal yang berasal dari luar siswa antara lain kurangnya variasi mengajar guru, penggunaan media pembelajaran yang belum maksimal, serta lingkungan keluarga.

\section{KESIMPULAN}

Berdasarkan penyajian data dan pembahasan. Penelitian mengenai Studi Kasus Kesulitan Belajar Matematika di Kelas X SMAIT Al Auliya Balikpapan, maka diperoleh kesimpulan persentase rata - rata kesulitan belajar matematika siswa dengan melihat tingkat kesalahan siswa dalam menyelesaikan soal tes yaitu, tahap mengingat (C1) $41 \%$, tahap memahami (C2) 63,5\%, tahap menerapkan (C3) $68,75 \%$, tahap menganalisa (C4) $77,25 \%$.

Selanjutnya, faktor yang menyebabkan kesulitan belajar matematika berasal dari faktor internal dan faktor eksternal. Faktor internal terlihat dari sebagian siswa memiliki minat belajar yang kurang, terutama dalam belajar matematika. Ada yang belajar hanya saat akan ulangan, ada yang mengobrol saat belajar, ada pula yang malas dalam belajar matematika.
Selain itu, siswa yang kesulitan dalam matematika pada umumnya memiliki sikap negatif saat pembelajaran matematika, seperti: bertindak gaduh, tidak memperhatikan ketika pembelajaran matematika berlangsung, siswa tidak antusias, dan siswa cenderung tidak aktif dalam pembelajaran. Sebagian siswa memiliki daya ingat yang rendah terhadap rumus maupun pengertian - pengertian mengenai matematika. Motivasi belajar siswa yang masih rendah. Kesehatan tubuh yang tidak optimal. Kemampuan pengindraan siswa yang kurang.

Adapun faktor eksternal yang menyebabkan kesulitan belajar matematika yaitu kurangnya variasi mengajar guru, penggunaan media pembelajaran yang belum maksimal, serta kurangnya perhatian dan dukungan dari keluarga baik orang tua maupun saudara.

\section{DAFTAR PUSTAKA}

Abdurrahman, Mulyono. (2010). Pendidikan Bagi Anak Berkesulitan Belajar. Jakarta: Rineka Cipta.

Ahmadi, Abu dan Widodo Supriyono. (2013). Psikologi Belajar. Jakarta: PT Rineka Cipta.

Amelia, Diona dan Susanto. (2015). Analisis Hasil Belajar Matematika Siswa Pada Pokok Bahasan Himpunan Berdasarkan Ranah Kognitif Bloom Kelas VII-A di SMPN 14 Jember. Jurnal Edukasi.

Anderson, L.W dan Krathwohl, D.R. (2010). Kerangka Landasan untuk Pembelajaran, Pengajaran, dan Asesmen (Revisi Taksonomi Pendidikan Bloom). Yogyakarta: Pustaka Pelajar.

Chaplin, J P. (2005). Kamus Lengkap Psikologi. Jakarta : Rajawali Press.

Heruman. 2008. Model Pembelajaran

Matematika di Sekolah Dasar. Bandung: Remaja Rosdakarya.

Khasanah, Sugianti. (2015). Analisis Hasil Belajar Peserta Didik Pada Implementasi Scientific Approach Dalam Pembelajaran Kimia Materi 
Koloid di Kelas XI IPA SMA/MA. Skripsi. Hal 6.

Kementerian Pendidikan dan Kebudayaan, Dokumen Kurikulum 2013, Jakarta: Kemendikbud, 2012.

Kusdaryani, Wiwik dan Trimo. (2009). Landasan Kependidikan. IKIP PGRI Semarang Press.

Larkin, S. (2010). Metacognition in young children. Oxon: Routledge.

Lerner, J. W. (2006). Learning disabilities and related disorders. New York: Houghton Mifflin Company.

Mania, Sitti. (2012). Pengantar Evaluasi Pengajaran. Makasar: Alaudin University Press.

Muhibbin Syah. (2009). Psikologi Pendidikan dengan Pendekatan Baru. Bandung: PT. Remaja Rosdakarya.

Novferma, N. (2016). Analisis Kesulitan dan Self-Efficacy Siswa SMP dalam Pemecahan Masalah Matematika Berbentuk Soal Cerita. Jurnal Riset Pendidikan Matematika. Volume 3, No 1, hal 76-87. ISSN: 2356-2684.

Oemarjoedi, A.K. (2003). Pendekatan Cognitive Behavior dalam Psikoterapi. Jakarta: Kreativ Media.

Silitonga, F. A., \& Verawati, I. Hubungan Tingkat Kebugaran Jasmani Dengan Prestasi Belajar Siswa Putra Kelas Xi Sma N 1 Sipahutar Tapanuli Utara. Kesehatan dan Olahraga, 3(1), 29-38.

Slameto. (2010). Belajar dan Faktorfaktor yang Mempengaruhinya. Jakarta: Bina Aksara.

Subini, Nini. (2011). Mengatasi Kesulitan Belajar Pada Anak. Jogjakarta: Javalitera

Suryawati dan Yulfikar. (2012). Kualitas Tes dan Hasil Belajar Matematika Siswa Kelas VIII SMP Negeri Banda Aceh Tahun Pelajaran 2011/2012, Jurnal Peluang. Volume 1, No 1, hal 72.

Susanti, A., \& Nuriyatin, S. (2015). Pengaruh Motivasi Belajar Siswa terhadap Prestasi Belajar
Matematika Siswa (Effect on Student Motivation to Learn Mathematics Achievement of Student). Jurnal Pendidikan Matematika STKIP PGRI Sidoarjo, 3(2), 151-158.

Suwarto. (2013). Pengembangan tes diagnostik dalam pembelajaran. Yogyakarta: Pustaka Pelajar (Anggota IKAPI).

Tias, Ayu Aji Wedaring \& Dhoriva U.W. (2015). Analisis Kesulitan Siswa SMA dalam Pemecahan Masalah Matematika Kelas XII IPA di Kota Yogyakarta, Jurnal Riset Pendidikan Matematika. Volume 2, No 1, hal 2839. ISSN: 2356-2684. 